\section{PERWUJUDAN PRINSIP EQUALITY BEFORE THE LAW BAGI NARAPIDANA DI DALAM \\ LEMBAGA PEMASYARAKATAN DI INDONESIA ${ }^{1}$}

Oleh : Julita Melissa Walukow ${ }^{2}$

\begin{abstract}
ABSTRAK
Tujuan dilakukannya penelitian ini adalah untuk mengetahui bagaimana prinsip equality before the law dalam sistem pemasyarakatan dan bagaimana penerapan prinsip equality before the law bagi narapidana di Lembaga Pemasyarakatan dalam penegakan hukum dan hak asasi manusia. Berdasarkan penelitian hukum normatif disimpulkan bahwa: 1 . Pelaksanaan pembinaan narapidana oleh Lembaga Pemasyarakatan diatur dalam UU No. 12 Tahun 1995 tentang Pemasyarakatan yang menganut asas Equality Before the Law dan pelayanan yang dalam penjelasannya asas tersebut memiliki arti yaitu pemberian perlakuan dan pelayanan yang sama kepada Warga Binaan Pemasyarakatan tanpa membedabedakan orang. 2. Pada dasarnya UU No. 12 tahun 1995 mengatur tentang hak-hak narapidana, namun dalam pelaksanaannya ada hak-hak yang diberikan kepada narapidana yang memiliki golongan lebih di atas diluar daripada hak-hak yang diberikan yang ditulis dalam Undang-undang.

Kata Kunci: lembaga pemasyarakatan, Persamaan Hak
\end{abstract}

\section{A. LATAR BELAKANG}

Negara Republik Indonesia adalah Negara yang berdasarkan atas hukum. Undang-undang Dasar 1945 menetapkan bahwa Negara Republik Indonesia itu suatu negara hukum (rechstsaat) dibuktikan dari Ketentuan dalam pembukaan , Batang tubuh, dan Penjelasan Undang-undang Dasar 1945.

\footnotetext{
${ }^{1}$ Artikel skripsi.

${ }^{2}$ NIM: 090711012.
}

Dalam Amandemen Undang-undang Dasar 1945 , teori equality before the law termasuk dalam Pasal 27 ayat ( 1 ) yang menyatakan bahwa : Segala warga Negara bersamaan kedudukannya didalam hukum dan pemerintahan dan wajib menjunjung hukum dan pemerintahan itu dengan tidak ada kecualinya. ${ }^{3}$ Ini merupakan pengakuan dan jaminan hak kesamaan semua warganegara dalam hukum dan pemerintahan.

Teori dan konsep equality before the law seperti yang dianut oleh Pasal 27 ayat (1) Amandemen Undang-undang Dasar 1945 tersebut menjadi dasar perlindungan bagi warga Negara agar diperlakukan sama dihadapan hukum dan pemerintahan. Hal ini dimaksud, bahwa semua orang diperlakukan sama di depan hukum.

Equality before the law dalam arti sederhananya bahwa semua orang sama di depan hukum. Persamaan dihadapan hukum atau equality before the law adalah salah satu asas terpenting dalam hukum modern. Asas ini menjadi salah satu sendi doktrin Rule of Law yang juga menyebar pada negara-negara berkembang seperti Indonesia.

Kalau dapat disebutkan asas equality before the law ini merupakan salah satu manifestasi dari Negara hukum (rechtstaat) sehingga harus adanya perlakuan sama bagi setiap orang di depan hukum (gelijkheid van ieder voor de wet). ${ }^{4}$ Dengan demikian, elemen yang melekat mengandung makna perlindungan sama di depan hukum (equal justice under the law) dan mendapatkan keadilan yang sama di depan hukum.

Perundang-undangan Indonesia mengadopsi asas ini sejak masa kolonial lewat Burgelijke Wetboek (KUHPerdata) dan Wetboek van Koophandel voor

\footnotetext{
3 Yasir Arafat. Undang-undang Dasar Republik Indonesia 1945 dan perubahannya, Permata Press. hal 26.

4 Lilik Mulyadi, Hukum Acara Pidana, Citra Aditya Bakti, Jakarta, 2007, hal. 20.
} 
Indonesie (KUHDagang) pada 30 April 1847 melalui Stb. 1847 No. 23. Tapi pada masa kolonial itu, asas ini tidak sepenuhnya diterapkan karena politik pluralisme hukum yang memberi ruang berbeda bagi hukum Islam dan hukum adat disamping hukum kolonial.

Asas persamaan dihadapan hukum merupakan asas dimana terdapatnya suatu kesetaraan dalam hukum pada setiap individu tanpa ada suatu pengecualian. Asas persamaan dihadapan hukum itu bisa dijadikan sebagai standar untuk mengafirmasi kelompok-kelompok marjinal atau kelompok minoritas. Namun disisi lain, karena ketimpangan sumberdaya (kekuasaan, modal dan informasi) asas tersebut sering didominasi oleh penguasa dan pemodal sebagai tameng untuk melindungi aset dan kekuasaannya.

Asas equality before the law bergerak dalam payung hukum yang berlaku umum (general) dan tunggal. Ketunggalan hukum itu menjadi satu wajah utuh di antara dimensi sosial lain, misalnya terhadap ekonomi dan sosial. Persamaan "hanya" di hadapan hukum seakan memberikan sinyal di dalamnya, bahwa secara sosial dan ekonomi orang boleh tidak mendapatkan persamaan. Perbedaan perlakuan "persamaan" antara di dalam wilayah hukum, wilayah sosial dan wilayah ekonomi itulah yang menjadikan asas equality before the law tergerus di tengah dinamika sosial dan ekonomi.

Hukum acara pidana tidak mengenal adanya peraturan yang memberikan perlakuan khusus kepada terdakwa sehingga pengadilan mengadili dengan tidak membeda-bedakan orang sebagaimana ditentukan Pasal 5 ayat (1) Undang-undang Nomor 14 Tahun 1970 jo. Undang-undang Nomor 35 Tahun 1999 jo. Undang-undang Nomor 4 Tahun 2004 dan penjelasan umum angka 3 huruf (a).

Salah satu ciri penting dalam konsep negara hukum The Rule of Law adalah
Equality before the Law atau persamaan dalam hukum selain dari supremasi hukum (Supremacy of Law) dan hak asasi manusia (Human Rights). Penerapan dari asas ini dilaksanakan oleh aparat penegak hukum, salah satunya yaitu Lembaga Pemasyarakatan. Pelaksanaan pidana penjara dengan sistem pemasyarakatan memang merupakan bagian dari satu rangkaian penegakan hukum pidana atau bagian dari rangkaian sistem peradilan pidana (criminal justice system) di Indonesia. ${ }^{5}$

Di dalam Undang undang Nomor 12 Tahun 1995 pasal 5 menyatakan bahwa: "Sistem pemasyarakatan dilaksanakan berdasarkan asas pengayoman, persamaan perlakukan dan pelayanan pendidikan, penghormatan harkat dan martabat manusia, kehilangan kemerdekaan adalah salah satu derita, serta terjaminnya hak untuk berhubungan dengan keluarga dan orang-orang tertentu sangat diperlukan bagi narapidana". 6

Lembaga Pemasyarakatan merupakan salah satu komponen penting dalam sistem peradilan pidana yang memiliki fungsi paling strategis serta potensial untuk memperbaiki para narapidana agar dibina sehingga diharapkan mereka yang pernah melakukan kejahatan tidak mengulangi lagi kejahatannya.

Sedangkan dalam Pasal 28 ayat (3) Peraturan Pemerintah Nomor 32 Tahun 1999 tentang Syarat dan Tata cara Pelaksanaan Warga Binaan Pemasyarakatan,menyatakan bahwa: Narapidana dan Anak Didik Pemasyarakatan dilarang membawa pesawat televisi dan radio atau media elektronik yang lain ke dalam LAPAS untuk kepentingan pribadi.

\footnotetext{
5 Romli Atmasasmita, Kapita Selekta Hukum Pidana dan Kriminologi, Mandar Maju, Bandung, 1995, hal. 157.

6 Indonesia, Undang-undang No. 12 Tahun 1995 tentang pemasyarakatan, Pasal 5
} 
Pelaksanaan pembinaan narapidana oleh Lembaga Pemasyarakatan diatur dalam Undang-Undang No. 12 Tahun 1995 tentang Pemasyarakatan yang menganut asas persamaan perlakuan dan pelayanan yang dalam penjelasannya asas tersebut memiliki arti yaitu pemberian perlakuan dan pelayanan yang sama kepada Warga Binaan Pemasyarakatan tanpa membedabedakan orang sebagai asas secara khusus, hanya saja seperti kita ketahui saat ini sering terjadi perlakuan-perlakuan khusus yang diberikan kepada narapidana dari golongan atas khususnya para pejabat pemerintah seperti pemberian fasilitas yang tidak diberikan pada narapidana lain yang berasal dari golongan bawah. Hukum yang seharusnya bersifat netral bagi Narapidana, seringkali bersifat diskriminatif , memihak kepada yang kuat dan berkuasa.

Perubahan sistem pemidanaan di Indonesia ke arah Pemasyarakatan pada hakekatnya merupakan perubahan ke arah sistem pemidanaan yang manusiawi dan melindungi HAM. Bahkan Pemasyarakatan dalam arti sesungguhnya merupakan proses penegakan hukum yang berorientasi pada perlindungan HAM, khususnya hakhak warga binaan Pemasyarakatan. Namun kenyataan sekarang ini, pelaksanaan sistem ini belum didukung aspek organisasi dan fasilitatif yang memadai serta adaptasi terhadap perkembangan pemidanaan di dunia.

Permasalahan hukum di Indonesia terjadi karena beberapa hal, baik dari system peradilannya, perangkat hukumnya, inkonsistensi penegakan hukum, intervensi kekuasaan, maupun perlindungan hukum . Diantara banyaknya permasalahan tersebut, satu hal yang sering dilihat dan dirasakan oleh masyarakat awam adalah adanya inkonsistensi penegakan hukum oleh aparat. Inkonsistensi penegakan hukum ini kadang melibatkan masyarakat itu sendiri, keluarga, maupun lingkungan terdekatnya yang lain (tetangga, teman, dan sebagainya). Namun inkonsistensi penegakan hukum ini sering pula mereka temui dalam media elektronik maupun cetak, yang menyangkut tokoh-tokoh masyarakat (pejabat, orang kaya, dan sebagainya).

Pada umumnya para narapidana yang berada di dalam Lembaga Pemasyarakatan seharusnya tidak memiliki fasilitas yang mewah,bahkan didalam kamar tahanan tidak boleh diberikan fasilitas seperti TV, AC, Sofa, dan sebagainya. Tapi, dalam kenyataannya pemberian fasilitas seperti itu malah didapatkan di dalam kamar narapidana yang memliki jabatan,kedudukan, dan kekayaan. Sedangkan bagi Narapidana yang tidak mempunyai apa-apa tidak bisa mendapatkan fasilitas seperti itu. Peraturan yang sudah dibuat tidak sebanding dengan praktek yang ada. Karena itu, berbagai peristiwa hukum saat ini semakin membuka mata bahwa hukum di negeri ini hanya berpihak pada yang kuat, dan mempunyai kedudukan, apalagi bila mempunyai kekayaan yang banyak.

Dengan latar belakang tersebut, maka dalam penulisan Skripsi Penulis mengangkat judul "Perwujudan Prinsip Equality Before the Law bagi Narapidana di dalam Lembaga Pemasyaraktan di Indonesia".

\section{B. PERUMUSAN MASALAH}

1. Bagaimana prinsip equality before the law dalam sistem pemasyarakatan?

2. Bagaimanakah penerapan prinsip equality before the law bagi narapidana di Lembaga Pemasyarakatan dalam penegakan hukum dan hak asasi manusia?

\section{METODE PENELITIAN}

Untuk menghimpun bahan yang diperlukan guna penulisan skripsi ini penulis menggunakan metode penelitian kepustakaan (library research), yaitu 
dengan mempelajari pustaka hukum, artikel-artikel hukum, himpunan peraturan perundang-undangan dan sumber-sumber tertulis lainnya. Seperti Undang-Undang No 12 tahun 1995 tentang Lembaga Pemasyarakatan. Dengan demikian, analisis yang digunakan merupakan analisis normatif.

\section{F. PEMBAHASAN}

\section{Prinsip Equality Before the Law dalam Sistem Pemasyarakatan.}

Persamaan kedudukan dihadapan hukum atau equality before the law adalah salah satu asas terpenting dalam hukum modern. Asas ini menjadi salah satu sendi doktrin Rule of Law yang juga menyebar pada negara-negara berkembang seperti Indonesia.

Prinsip Negara hukum mengajarkan bahwa komunikasi dan interaksi sosial yang terdiri dari berbagai elemen komunitas berinteraksi dan bertransaksi untuk mencapai tujuan dan cita-cita bersama. Bahwa tatanan kehidupan dan komunikasi antar individu dalam suatu komunitas mengacu kepada aturan main yang disepakati dan dipakai sebagai acuan dan referensi para pihak dalam melakukan hubungan dan perbuatan hukum. Atas dasar konsep tersebut, tidak ada kesemena-menaan yang dilakukan baik oleh penegak hukum maupun oleh pencari keadilan, sehingga melahirkan masyarakat sipil (civil society)di mana antar individu sebagai rakyat atau warga Negara mempunyai kedudukan yang sama dan sederajat di depan hukum (equality before the law).

Asas Equality before the law jika di kaitkan dengan fungsi peradilan, berarti setiap orang yang datang berhadapan di sidang peradilan adalah "sama hak dan kedudukaannya" begitu juga saat seorang sudah di nyatakan sebagai narapidana, saat berada di dalam lembaga pemasyarakatan narapidana juga memiliki perlakuan hak dan kedudukan yang sama.

Persamaan di depan hukum berarti sama dengan persamaan di dalam Lembaga pemasyarakatan. Secara tegas dikatakan; bahwa semua orang mempunyai kedudukan yang sama di depan hukum berarti sama dengan semua orang mempunyai kedudukan yang sama di dalam penjara. Hal ini berkaitan erat dengan norma dan rasa keadilan di dalam hukum.

Semua orang mempunyai kedudukan yang sama di depan hukum berarti sama dengan semua orang mempunyai kedudukan yang sama di dalam Lembaga pemasyarakatan. Semua orang adalah subyek hukum. Tidak peduli kaya atau miskin, anak presiden atau anak pengemis, bahkan tidak peduli sebelumnya berstatus pejabat atau pengangguran. Semuanya sama. Yang berpangkat harus menanggalkan kepangkatannya, yang anak presiden harus meninggalkan semua fasilitas dan kemewahan yang pernah dimilikinya, yang kaya harus meninggalkan kekayaan dan gaya hidupnya. Dalam hal tertentu, asas persamaan dihadapan hukum itu bisa dijadikan sebagai standar untuk mengafirmasi kelompok-kelompok marjinal atau kelompok minoritas.

Salah satu tujuan dari pemasyarakatan ialah memberikan jaminan perlindungan hak asasi tahanan yang di tahan di rumah tahanan Negara dan cabang rumah tahanan dalam rangka memperlancar proses peyidikan, penuntutan, dan pemeriksaan di siding pengadilan.

Sistem pemasyarakatan yang dimuat dalam ketentuan Pasal 1 angka 2 UndangUndang Nomor 12 Tahun 1995 tentang Pemasyarakatan tersebut dalam melaksanakan pembinaan terhadap narapidana didasarkan pada beberapa hal, sebagaimana tercantum dalam Pasal 5 Undang-Undang Nomor 12 Tahun 1995 tentang Pemasyarakatan menegaskan 
sistem pemasyarakatan yang dilaksanakan berdasarkan asas-asas sebagai berikut :

1. Pengayoman

Menurut Penjelasan pasal 5 UndangUndang Nomor 12 Tahun 1995 yang di maksud degan pengayoman adalah perlakuan terhadap warga binaan pemasyarakatan dalam rangka melindungi masyarakat dari kemungkinan diulanginya tindak pidana oleh warga binaan pemasyarakatan. Selain itu juga memberikan bekal hidup kepada warga binaan pemasyarakatan agar ,menjadi warga yang berguna di dalam masyarakat.

2. Persamaan perlakuan dan pelayanan

Menurut penjelasan pasal 5 UndangUndang No 12 tahun 1995 yang di maksud dengan persamaan perlakuan dan pelayanan adalah pemberian perlakuan dan pelayanan yang sama kepada warga binaan pemasyarakatan tanpa membeda-bedakan orang.

3. Pendidikan dan Pembimbingan

Proses pendidikan dan pembimbingan dilaksanakan berdasarkan pancasila, seperti penanaman jiwa kekeluargaan, keterampilan, pendidikan kerohanian, dan kesempatan untuk menunaikan ibadah.

4. Penghormatan harkat dan martabat manusia

Penghormatan harkat dan martabat manusia dimaksudkan bahwa sebagai orang yang tersesat, warga binaan pemasyarakatan harus tetap diperlakukan sebagai manusia.

5. Kehilangan kemerdekaan merupakan satu-satunya penderitaan

Warga binaan pemasyarakatan harus berada di dalam lembaga pemasyarakatan (lapas) untuk jangka waktu tertentu, sehingga negara memiliki kesempatan penuh untuk memperbaikinya. Selama di lapas, warga binaan pemasyarakatan (Narapidana) tetap memperoleh hak- haknya yang lain seperti layaknya manusia. Dengan kata lain, hak perdatanya tetap dilindungi, seperti hak memperoleh perawatan kesehatan, makan, minum, pakaian, tempat tidur, latihan keterampilan, olahraga, dan rekreasi.

6. Terjaminya hak untuk tetap berhubungan dengan keluarga dan orang-orang tertentu.

Meskipun warga binaan pemasyarakatan (narapidana) berada di lapas, harus tetap di dekatkan dan dikenalkan dengan masyarakat dan tidak boleh di asingkan dari masyarakat, seperti berhubungan dengan masyarakat dalam bentuk kunjungan, hiburan ke dalam lapas dari anggota masyarakat yang bebas, serta kesempatan berkumpul bersama sahabat dan keluarga seperti program cuti mengunjungi keluarga. ${ }^{7}$

Sistem Pemasyarakatan menitikberatkan pada usaha perawatan, pembinaan, pendidikan, dan bimbingan bagi warga binaan yang bertujuan untuk memulihkan kesatuan hubungan yang asasi antara individu warga binaan dan masyarakat. Pelaksanaan pembinaan pemasyarakatan didasarkan atas prinsip-prinsip sistem pemasyarakatan untuk merawat, membina, mendidik dan membimbing warga binaan dengan tujuan agar menjadi warga yang baik dan berguna.

Warga binaan dalam sistem pemasyarakatan mempunyai hak untuk mendapatkan pembinaan rohani dan jasmani hak mereka untuk menjalankan ibadahnya, berhubungan dengan pihak luar baik keluarganya maupun pihak lain, memperoleh informasi, baik melalui media cetak maupun elektronik, memperoleh pendidikan yang layak dan

${ }^{7}$ Marbun, Rocky. Op.cit,hal. 71 
sebagainya. Hak-hak itu tidak diperoleh secara otomatis tapi dengan syarat atau kriteria tertentu seperti halnya untuk mendapat remisi, asimilasi harus memenuhi syarat yang sudah ditentukan. $^{8}$

Sistem pemasyarakatan memandang pemidanaan yang berdasarkan pembinaan di dalam Lembaga Pemasyarakatan dengan suatu aturan hukum yang diintegrasikan antara pemulihan narapidana dengan pembalasan atas perbuatannya yang bertujuan supaya ada pertobatan.

Sistem pemasyarakatan merupakan suatu rangkaian kesatuan penegakan hukum pidana, oleh karena itu pelaksaananya tidak dapat dipisahkan dari pengembangan konsepsi umum mengenai pemidanaan.

Pembinaan Warga Binaan Pemasyarakatan di LAPAS dilaksanakan secara intramural (di dalam LAPAS) dan secara ekstramural (di luar LAPAS). Pembinaan secara ekstramural yang dilakukan di LAPAS disebut asimilasi, yaitu proses pembinaan Warga Binaan Pemasyarakatan yang telah memenuhi persyaratan tertentu dengan membaurkan mereka ke dalam kehidupan masyarakat. Pembinaan secara ekstramural juga dilakukan oleh BAPAS yang disebut integrasi, yaitu proses pembimbingan Warga Binaan Pemasyarakatan yang telah memenuhi persyaratan tertentu untuk hidup dan berada kembali di tengah-tengah masyarakat dengan bimbingan dan pengawasan BAPAS.

Pembinaan dan pembimbingan kepribadian dan kemandirian sebagaimana dimaksud dalam Pasal 2, meliputi hal-hal yang berkaitan dengan:

a. Ketaqwaan kepada Tuhan Yang Maha Esa;

\footnotetext{
${ }^{8}$ Peraturan Pemerintah Republik Indonesia No. 32 Tahun 1999 tentang Syarat dan Tata Cara Pelaksanaan Hak Warga Binaan Pemasyarakatan, Pasal. 1.
}

b. Kesadaran berbangsa dan bernegara;

c. Intelektual;

d. Sikap dan perilaku;

e. Kesehatan jasmani dan rohani;

f. Kesadaran hukum;

g. Reintegrasi sehat dengan masyarakat;

h. Keterampilan kerja; dan

i. Latihan kerja dan produksi. ${ }^{9}$

Sedangkan dalam pasal 4 di katakan bahwa Pelaksanaan pembinaan dan pembimbingan Warga Binaan Pemasyarakatan dilakukan oleh Petugas Pemasyarakatan yang terdiri dari atas:

a. Pembina Pemasyarakatan;

b. Pengaman Pemasyarakatan; dan

c. Pembimbing Kemasyarakatan. ${ }^{10}$

Dalam pasal 7 ayat (2) dan pasal 9

Peraturan Pemerintah No. 31 tahun 1999 mengatakan bahwa Tahap pembinaan sebagaimana dimaksud dalam ayat (1) terdiri dari atas 3 (tiga) tahap, yaitu:

a. Tahap awal

Pembinaan tahap awal dimulai sejak yang bersangkutan berstatus sebagai Narapidana sampai dengan $1 / 3$ (satu per tiga) dari masa pidana.

b. Tahap lanjutan

Pembinaan tahap lanjutan meliputi:

1. tahap lanjutan pertama, sejak berakhirnya pembinaan tahap awal sampai dengan $1 / 2$ (satu per dua) dari masa pidana; dan

2. tahap lanjutan kedua, sejak berakhirnya pembinaan tahap lanjutan pertama sampai dengan 2/3 (dua per tiga) masa pidana.

c. Tahap akhir

Pembinaan tahap akhir dilakasanakan sejak berakhirnya tahap lanjutan sampai dengan berakhirnya masa pidana dari Narapidana yang bersangkutan.

\footnotetext{
9 Peraturan Pemerintah Republik Indonesia Nomor 31 Tahun 1999 tentang Pembinaan dan Pembimbingan Warga Binaan Pemasyarakatan, pasal. 3.

10 Ibid
} 
Undang-Undang Nomor 12 Tahun 1995 tentang Pemasyarakatan secara tegas mengatur tentang hak-hak yang dimiliki oleh narapidana. Pada Pasal 14 UndangUndang Nomor 12 Tahun 1995 tentang Pemasyarakatan menentukan bahwa Narapidana berhak :

1. Melakukan ibadah sesuai dengan agama dan kepercayaanya.

2. Mendapat perawatan, baik perawatan rohani maupun jasmani.

3. Mendapat pendidikan dan pengajaran.

4. Mendapat pelayanan kesehatan dan makanan yang layak.

5. Menyampaikan keluhan

6. Mendapatkan bahan bacaan dan mengikuti siaran media massa lainnya yang tidak dilarang.

7. Mendapat upah atau premi atas pekerjaan yang dilakukan.

8. Menerima kunjungan keluarga, penasehat hukum atau orang tertentu lainnya.

9. Mendapatkan pengurangan masa pidana atau remisi.

10. Mendapatkan kesempatan berasimilasi termasuk cuti mengunjungi keluarga.

11. Mendapat pembebasan bersyarat.

12. Mendapatkan cuti menjelang bebas.

13. Mendapatkan hak-hak sesuai dengan peraturan perundang-undangan yang berlaku. ${ }^{11}$

Pendidikan dan pengajaran adalah usaha sadar untuk menyiapkan Warga Binaan Pemasyarakatan melalui kegiatan bimbingan atau latihan bagi peranannya di masa yang akan datang. Sedangkan untuk pelayanan kesehatan adalah upaya promotif,preventif, kuratif, dan rehabilitatif dibidang kesehatan bagi narapidana dan anak didik pemasyarakatan di lembaga pemasyarakatan.

Salah satu prinsip equality before the law dalam sistem pemasyarakatan adalah

\footnotetext{
${ }^{11}$ UU No. 12 tahun 1995 tentang Pemasyarakatan, Pasal 14.
}

pemberian remisi atau pengurangan masa menjalani pidana yang diberikan kepada Narapidana yang memenuhi syarat-syarat yang ditentukan dalam peraturan perundang-undangan.

\section{B. Penerapan Prinsip Equality Before the Law Bagi Narapidana di Lembaga Pemasyarakatan dalam Penegakan Hukum dan Hak Asasi Manusia}

Lembaga Pemasyarakatan sebagai ujung tombak pelaksanaan asas pengayoman merupakan tempat untuk mencapai tujuan tersebut melalui pendidikan, rehabilitasi dan reintegrasi. Sejalan dengan peran Lembaga Pemasyarakatan tersebut maka tepatlah apabila Petugas Pemasyarakatan melaksanakan tugas pembinanaan dan pengamanan Warga Binaan Pemasyarakatan dalam Undang-Undang di tetapkan sebagai Pejabat Fungsional Penegak Hukum.

Pembinaan dalam Lembaga Pemasyarakatan dapat terlaksana secara konfrehensif terhadap narapidana. Sebab terapi medis dan rehabilitasi sosial terhadap narapidana agar memberi manfaat dalam pemulihan bagi warga binaan. Kemanfaatan hukum bagi narapidana sebagai sistem pemidanaan dalam pandangan utilitarian (utilitarian view) menyatakan bahwa pemidanaan itu harus dilihat dari segi manfaatnya. Menurut pandangan utilitarian tujuan hukum dari segi manfaat dan kegunaannya yang dilihat adalah situasi atau keadaan yang ingin dihasilkan dengan dijatuhkan pidana itu.

Dalam melaksanakan pembinaan sebagaimana dimaksud dalam ayat (1), Kepala LAPAS menetapkan Petugas Pemasyarakatan yang bertugas sebagai Wali Narapidana dan Anak Didik Pemasyarakatan.

Dalam Konferensi Dinas Direktorat Pemasyarakatan di Lembang Jawa Barat, tanggal 27 April 1964 dirumuskan prinsipprinsip pokok yang menyangkut perlakuan 
terhadap narapidana dan anak didi sebagai berikut :

1. Ayomi dan berikan bekal hidup agar mereka dapat menjalankan peranan sebagai warga masyarakat yang baik dan berguna;

2. Penjatuhan pidana bukan tindakan balas dendam oleh negara. Ini berarti bahwa tidak boleh ada penyiksaan terhadap narapidana dan anak didik, baik yang berupa tindakan, perlakuan, ucapan cara perawatan ataupun penempatan. Satu-satunya derita yang dialami oleh narapidana dan anak didik hendaknya hanyalah dihilangkannya kemerdekaannya untuk bergerak dalam masyarakat bebas.

3. Berikan bimbingan, bukan penyiksaan, supaya mereka bertobat. Berikan kepada mereka pengertian mengenai norma-norma hidup dan kehidupan, dan sertakan mereka dalam kegiatankegiatan sosila untuk menumbuhkan rasa hidup kemasyarakatannya.

4. Negara tidak berhak membuat mereka menjadi lebih buruk atau lebih jahat daripada sebelumnya dijatuhi pidana, mialnya dengan mencampurbaurkan narapidana dan anak didik, yang melakukan tindak pidana berat dengan yang ringan, dan sebagainya.

5. Selama kehilangan kemerdekaan bergerak, para narapidana dan anak didik harus dikenalkan dengan dan tidak boleh diasingkan dari masyarakat. Antara lain kontak dengan masyarakat dapat menjelma dalam bentuk kunjungan hiburan ke dalam lembaga pemasyarakatan dari anggota-anggota masyarakat bebas, dan kesempatan yang lebih banyak untuk berkumpul bersama sahabat dan keluarga;

6. Pekerjaan yang diberikan kepada narapidana dan anak didik tidak boleh bersifat sekedar pengisi waktu. Juga tidak boleh diberikan pekerjaan untuk memenuhi kebutuhan jawatan atau kepentingan negara pada waktu-waktu tertentu saja. Pekerjaan yang diberikan harus satu dengan pekerjaan yang terdapat di masyarakat, dan yang menunjang pembangunan, umpamanya menunjang usaha meningkatkan produksi pangan.

7. Bimbingan dan didikan yang diberikan kepada narapidana dan anak didik harus berdasarkan Pancasila. Antara lain ini berarti bahwa kepada mereka harus ditanamkan jiwa kegotongroyakan, jiwa toleransi, jiwa kekeluargaan, disamping pendidikan kerokhanian dan kesempatan untuk menunaikan ibadah agar memperoleh kekuatan spiritual;

8. Narapidana dan anak didik sebagai orang-orang yang tersesat adalah manusia, dan mereka harus diperlakukan sebagai manusia. Martabatnya dan persaannya sebagai manusia harus dihormati;

9. Narapidana dan anak didik hanya dijatuhkan narapidana hilang kemerdekaan sebagai satu-satunya derita yang dapat dialaminya;

10. Disediakan dan dipupul sarana-sarana yang dapat mendukung fungsi rehabilitatif, korektif dan edukatif dalam sistem pemasyarakatan. ${ }^{12}$

Kesepuluh prinsip yang dihasilkan dalam Konferensi Lembang tanggal 27 April 1964 tersebut sangat baik sebagai pedoman untuk pembinaan narapidana dan anak didik. Oleh karena itu, sebaiknya para petugas lembaga pemasyarakatan di seluruh Indonesia berusaha semaksimal mungkin untuk melaksanakan hasil konferensi tersebut. Dengan demikian perlakuan terhadap narapidana dan anak didk, tiada lain ialah melakukan pembinaan, agar narapidana itu menjadi manusia yang berguna di masa mendatang.

\footnotetext{
${ }^{12}$ Romli Atmasasmita, Fungsi pidana penjara dalam sistem pemidanaan di Indonesia, Bandung, Alumni, 1982, hal 70
} 
Berbicara tentang penegakan hukum berarti berbicara juga tentang hukum itu sendiri. Di dalam ilmu hukum mengenal asas equality before the law, dimana semua orang mempunyai kedudukan yang sama di depan hukum.

Asas equality before the Law atau persamaan dalam hukum, supremasi hukum dan hak asasi manusia merupakan syarat dari konsep negara hukum. ${ }^{13}$ Atas konsepsi itulah kebijakan-kebijakan menyangkut regulasi yang dikeluarkan oleh pemerintah serta implementasi atas kebijakan-kebijakan harus mengedepankan aspek hak asasi manusia. Aturan tentang hak asasi manusia yang melekat pada setiap manusia diatur lewat seperangkat aturan hukum yang ada. ${ }^{14}$ Dalam pelaksanaannya di Indonesia peraturan pelaksana terhadap hak-hak asasi tersebut tertuang dalam Undang-undang Nomor 39 Tahun 1999 tentang Hak Asasi Manusia merupakan salah satu perangkat aturan hukum yang menjadi acuan dan mengatur tentang hak asasi manusia di Indonesia. Berbicara tentang hak asasi manusia, setiap orang memiliki hak asasi yang sama tidak terkecuali orang yang menjalani hukuman. Salah satu bentuk hak asasi yang diberikan negara adalah hak pembinaan bagi narapidana. Secara umum narapidana juga merupakan warga negara namun yang membedakannya adalah lingkungannya. Dalam Pasal 1 ayat (7) Undang-undang Nomor 12 Tahun 1995 tentang Pemasyarakatan. Narapidana adalah orang yang menjalani pidana hilang kemerdekaan di Lembaga Pemasyarakatan.

\footnotetext{
${ }^{13}$ SF Marbun, Dimensi-Dimensi Pemikiran Hukum Administrasi Negara, UII Press, Yogyakarta, 2004, hal. 8

${ }^{14}$ A. Mansyur Effendi, Perkembangan Dimensi Hak Asasi Manusia dan Proses Dinamika Penyusunan Hukum Hak Asasi Manusia, Ghalia Indonesia, Bogor, 2005, hal. 32.
}

Persepsi masyarakat ketika mendengar istilah narapidana adalah orang-orang yang akibat perbuatannya, dihukum dalam penjara atau lembaga pemasyarakatan dan hukuman itu layak diberikan kepadanya sebagai konsekuensi dari perbuatannya. Merujuk Pasal 10 Kitab Undang-undang Hukum Pidana, jenis hukuman yang bisa diberikan berupa hukuman pokok dan hukuman tambahan. Hukuman pokok yaitu hukuman mati, hukuman penjara, hukuman kurungan dan hukuman denda, sedangkan hukuman tambahan yaitu pencabutan beberapa hak tertentu, perampasan barang tertentu dan pengumuman putusan hakim. Hukuman tersebut diberikan dan dilaksanakan oleh negara kepada setiap warga negara yang terbukti bersalah sesuai dengan putusan hakim yang telah memiliki kekuatan hukum tetap.

\section{G. PENUTUP}

1. Kesimpulan

1. Pelaksanaan pembinaan narapidana oleh Lembaga Pemasyarakatan diatur dalamUndang-Undang No. 12 Tahun 1995 tentang Pemasyarakatan yang menganut asas Equality Before the Law dan pelayanan yang dalam penjelasannya asas tersebut memiliki arti yaitu pemberian perlakuan dan pelayanan yang sama kepada Warga Binaan Pemasyarakatan tanpa membeda-bedakan orang.

2. Pada dasarnya Undang-Undang nomor 12 tahun 1995 mengatur tentang hakhak narapidana, namun dalam pelaksanaannya ada hak-hak yang diberikan kepada narapidana yang memiliki golongan lebih di atas diluar daripada hak-hak yang diberikan yang ditulis dalam Undang-undang. Sehingga perlakuan lembaga pemasyarakatan yang ada di Indonesia masih kurang baik. Hal ini terlihat kasus tentang perlakuan istimewa atau diskriminasi berdasarkan status sosial dan kedudukan, pada 
akhirnya prinsip equality before the law ini mempunyai kelemahan dalam penerapan di dalam lembaga pemasyarakatan

\section{Saran}

1. Tempatkan para narapidana dalam persamaan hak dan derajat di dalam Lembaga Pemasyarakatan. Berikan kepada mereka hak perlindungan hukum yang sama selama berada di dalam lembaga pemasyarakatan sesuai dengan Undang-Undang No. 12 Tahun 1995 tentang Pemasyarakatan. Layani mereka dengan hak perlakuan yang sama menurut hukum sejak mereka masuk dan keluar di lembaga pemasyarakatan

2. Pemerintah serta aparat penegak hukum dalam hal ini departemen hukum dan ham harus memberikan hukuman, sanksi atau tindakan tegas kepada petugas pemasyarakatan (sipir) yang melakukan perlakuan khusus di luar undang-undang yang mengatur kepada narapidana golongan di atas.

\section{DAFTAR PUSTAKA}

A Josias Simon R, Budaya Penjara Pemahaman dan Implementasi, Karya Putra Darwati, Bandung, 2012.

Andi Hamzah \& Siti Rahayu, Suatu Tinjauan Ringkas Sistem Pemidanaan Di Indonesia, Akademika Pressindo, Jakarta, 1983.

Lilik Mulyadi, Hukum Acara Pidana, Citra Aditya Bakti, Jakarta, 2007.

Mansyur A Effendi., Perkembangan Dimensi Hak Asasi Manusia dan Proses Dinamika Penyusunan Hukum Hak Asasi Manusia, Ghalia Indonesia, Bogor, 2005.

Marbun, Rocky., Cerdik dan Praktis Menghadapi Kasus Hukum, Visimedia, Jakarta, 2010

Muladi, HAM-Hakekat, Konsep \& Implikasinya Dalam Perspektif Hukum \& Masyarakat. Refika Aditama, Bandung, 2009.
Muladi, Lembaga Pidana

Bersyarat, Alumni, Bandung, 1985.

Romli Atmasasmita, Kapita Selekta Hukum Pidana dan Kriminologi, Mandar Maju, Bandung, 1995.

Romli Atmasasmita, Teori dan Kapita Selekta Krimonologi, Refika Aditama, Bandung, 2007.

Romli Atmasasmita, Fungsi Pidana Penjara Dalam Sistem Pemidanaan Di Indonesia,

SF Marbun, Dimensi-Dimensi Pemikiran Hukum Administrasi Negara, UII Press, Yogyakarta, 2004.

Suharto \& Jonaedi Efendi, Paduan Praktis Bila Anda Menghadapi Perkara Pidana, Prestasi Pustaka, Jakarta, 2010.

Sumarsono A Karim, Bimbingan dan Penyuluhan Warga Binaan Pemasyarakatan (Anak Sipil, Anak Negara, Narapidana, dan Klien Pemasyarakatan), Jakarta, 2009.

Sumarsono A Karim, Metode dan Teknik Penelitian Kemasyarakatan, Jakarta, 2003.

Sumbu Telly dan kawan-kawan. Kamus Umum Hukum Dan Politik. Media Prima Aksara. Jakarta : 2011.

Utrecht, Pengantar Hukum Administrasi Negara Indonesia, Ichtiar, Jakarta, 1962

Kompilasi Instrumen Internasional Hak Asasi Manusia dan Dokumen-dokumen terkait dengan Praktek dalam Lembaga Pemasyarakatan, 2008. 